\title{
Field Performance of Conventional vs. in Vitro Propagules of Plantain (Musa spp., AAB Group)
}

\author{
Dirk R. Vuylsteke ${ }^{1}$ and Rodomiro Ortiz ${ }^{2}$ \\ Plantain and Banana Improvement Program, International Institute of Tropical \\ Agriculture, Onne Station, PMB 5320, Ibadan, Nigeria
}

Additional index words. micropropagation, somaclonal variation, tissue culture

\begin{abstract}
In vitro-propagated plants of plantain (Musa spp., AAB group) did not manifest consistently superior horticultural performance compared to conventional propagules. Tissue culture plants grew vigorously and taller than sucker-propagated plants, but higher yield was not obtained, probably because of severe disease and suboptimal husbandry input. Phenotypic variation was higher in tissue culture plants, although this increase was not always statistically significant. There were no other detrimental effects of in vitro propagation on field performance. Botanical seed set rates for the two types of propagules were similar. The advantages of tissue-culture-derived plants as improved planting material would be most relevant for establishing field nurseries for further clean, conventional propagation of newly bred or selected genotypes.
\end{abstract}

The advantages of in vitro micropropagation include higher rates of multiplication; production of clean, or disease-free, planting material; and the small amount of space required to multiply large numbers of plants. These advantages of micropropagation are particularly relevant to vegetatively propagated crops, such as banana and plantain (Musa spp. L.), in which germplasm handling typically is fraught with such obstacles as slow multiplication, bulkiness, and poor phytosanitary quality of conventional propagules. Hence, in vitro, shoot-tip culture is a vital technical adjunct to any international Musa breeding program for multiplication and dissemination of newly bred clones. Thus, development of a shoot-tip culture technique for micropropagation of Musa has received considerable attention during the past 15 years and since has become well established (Cronauer and Krikorian, 1984; Hwang et al., 1984; Jarret et al., 1985; Smith and Drew, 1990; Vuylsteke, 1989; Vuylsteke and De Langhe, 1985).

Several authors have documented the field performance of micropropagated bananas, with a strong bias toward cultivars of the 'Cavendish' subgroup (Musa spp., AAA group), which constitute the bulk of the inter-

Received for publication 13 July 1995. Accepted for publication 7 Mar. 1996. The International Institute of Tropical Agriculture is a nonprofit organization and a member of the Consultative Group on International Agricultural Research. Its international mailing address is IITA, c/o L.W. Lambourn \& Co., 26 Dingwall Rd., Croydon CR9 3EE, England. The cost of publishing this paper was defrayed in part by the payment of page charges. Under postal regulations, this paper therefore must be hereby marked advertisement solely to indicate this fact.

${ }^{1}$ Tissue Culturist and Germplasm Enhancer. Current address: IITA, P.O. Box 7878, Kampala, Uganda.

${ }^{2}$ Breeder and Geneticist. national banana trade. When compared with bananas propagated using conventional planting material (i.e., suckers), micropropagated banana plants were capable of performing equally or better (Hwang et al., 1984; Smith and Drew, 1990). In general, micropropagated banana plants established more quickly, grew more vigorously, were taller, had a shorter and more uniform production period, and produced higher yields than conventional propagules (Daniells, 1988; Drew and Smith, 1990; Hwang et al., 1984; Israeli et al., 1988; Robinson et al., 1993; Zamora et al., 1989). Yield gains from using in vitro plants ranged from $0 \%$ to $23 \%$, but this gain was sometimes confined to the plant crop only. Generally, superior performance of micropropagated bananas is attributable to propagules that already possess an active root and shoot system at planting time and are free of most diseases and pests (Drew and Smith, 1990).

However, the most significant problem that has arisen using in vitro-produced bananas is the ubiquitous occurrence of off-type plants or somaclonal variants (Israeli et al., 1991). Plantings of micropropagated 'Cavendish' bananas had $1 \%$ to $50 \%$ off-types (Smith, 1988), most of which were dwarfs with horticultural traits inferior to those of the original clone (Hwang and Ko, 1987; Smith and Drew, 1990; Stover, 1987). These frequencies of phenotypic variation are much higher than those for sucker-derived plantings of 'Cavendish' bananas, which have a mutation rate of about two per million per generation(Simmonds, 1966). Smith (1988) reviewed the factors influencing the occurrence of offtypes in micropropagated bananas, which led to procedures designed to minimize somaclonal variation (Reuveni and Israeli, 1990; Smith, 1988).

While micropropagated bananas of 'Cavendish' clones have been evaluated to a reasonable extent, plantains (Musa spp., AAB group) have not, although this is an important food crop in the tropical humid forest zone of Africa and America (Vuylsteke et al., 1993a). Some work has been done on the characterization of somaclonal variation in plantain (Ramcharan et al., 1987; Sandoval et al., 1991; Vuylsteke et al., 1991), but field performance of micropropagated vs. conventionally propagated plantains has not been documented. However, frequent use of micropropagation warrants such horticultural evaluation. In this paper, we report on the effect of propagation method on plantain growth and yield, rate of phenotypic variation, and botanical seed set.

\section{Materials and Methods}

We used the medium False Horn plantain 'Agbagba', the most widely cultivated and preferred clone in Nigeria. 'Agbagba' is susceptible to black sigatoka (Mycosphaerella fijiensis Morelet) and exhibits extremely high levels of female sterility. For the latter reason, the female-fertile French plantain 'Obino l'Ewai' was selected for comparison of botanical seed set rates between conventional and in vitro propagules.

Conventional propagules were vigorous "sword" suckers (i.e., lateral shoots) obtained from true-to-type plants. The latter were selected based on phenotypic descriptors (Tezenas du Montcel et al., 1983; Vuylsteke et al., 1988). Suckers were prepared and planted as recommended by Swennen (1990). Micropropagated plants were produced following standard shoot-tip culture techniques (Vuylsteke, 1989). Aseptic culture of 'Agbagba' was initiated from a single lateral bud collected from a field-grown plant known to be true-to-type for two successive production cycles. The bud was washed in running water for $30 \mathrm{sec}$ followed by a rinse in $70 \%$ ethanol for $1 \mathrm{~min}$, surface-disinfected in commercial bleach (10\% Clorox) for $15 \mathrm{~min}$, and rinsed in sterilized distilled water. A single shoot-tip $\approx 1 \mathrm{~cm}$ long was excised aseptically and split longitudinally in two halves that were cultured separately on $20 \mathrm{ml}$ proliferation medium in $150 \times 25$-mm culture tubes. The proliferation medium consisted of a modified Murashige and Skoog (1962) (MS) medium containing (in mg.liter ${ }^{-1}$ ) 20 ascorbic acid, 0.18 indole-3-acetic acid (IAA), and 4.5 6benzyladenine (BA) and was solidified with gellan gum (Phytagel, Sigma Chemical Co., St. Louis) at 2 g.liter ${ }^{-1}$ at $\mathrm{pH}$ 5.8. The medium was autoclaved for $15 \mathrm{~min}$ at $121 \mathrm{C}$. Multiplication of the two shoot-tip cultures proceeded through three serial subcultures on a monthly basis to produce 75 proliferating shoot cultures from which $>250$ plantlets were obtained. Rooting of proliferating shoots was achieved by placing small clusters of two to three shoots or buds on the same MS medium but without IAA and with 1-naphthaleneacetic acid (NAA) and BA at 0.19 and 0.23 $\mathrm{mg} \cdot$ liter $^{-1}$, respectively. All cultures were incubated in a culture room at 27 to $32 \mathrm{C}$ under a 14-h photoperiod ( 30 to $40 \mu \mathrm{mol} \cdot \mathrm{m}^{-2} \cdot \mathrm{s}^{-1}$ ) provided by cool-white fluorescent tubes. In vitro plants of 'Obino l'Ewai' were produced using 
the same methodology as for 'Agbagba', except that plants were produced from older shoot-tip cultures. Rooted plantlets were transferred to a nursery shed for acclimatization for 2 months before planting in the field.

Propagules of 'Agbagba' were planted in May 1991 using a completely randomized design with unequal replications. Five plots were planted with in vitro plants and four plots with suckers, each plot consisting of 49 plants in a $7 \times 7$ arrangement per replication. For comparison of growth and yield characteristics, only the 25 plants in the middle of the plot eliminated border effects. Plants were spaced at $3 \times 2 \mathrm{~m}$, providing a density of 1667 plants/

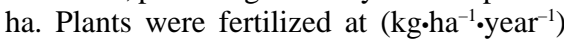
$300 \mathrm{~N}$ and $450 \mathrm{~K}$ split over six equal applications during the rainy season and using urea and muriate of potash, respectively.

Individual 'Agbagba' plants were assessed for growth and yield variables according to Swennen and De Langhe (1985) and Swennen and Vuylsteke (1987) and by visual scoring of black sigatoka disease severity using the youngest leaf spotted (YLS) measurement as described by Vakili (1968). Screening for phenotypic variation was performed by monitoring morphological descriptors of plantain (Tezenas du Montcel et al., 1983) to identify known variants (Vuylsteke et al., 1988, 1991). Off-types were not considered in the analysis of growth and yield variables of either propagule type.

Propagules of 'Obinol'Ewai' were planted in May 1988 with 98 plants of each propagule type in adjacent blocks of seven rows each with 14 plants. Spacing and cultural practices were similar to those used for 'Agbagba', except that a mulch was added to the plantain rows by pruning bush fallow hedgerows growing between rows. Female flowers of the emerging inflorescences were hand-pollinated with the wild, nonedible banana clone 'Calcutta 4' (Musa acuminata ssp. burmannicoides De Langhe and Devreux) and seeds were extracted and counted according to established protocols (Vuylsteke et al., 1993b). Only seed counts of pollinations conducted between 15 Apr. and 31 Dec. 1989 were included. There were no off-types in either population of 'Obino l'Ewai'.

Both trials were conducted at the Onne station (near Port Harcourt, Southeast Nigeria) of the International Institute of Tropical Agriculture, which is in the lowland humid forest zone of West Africa. Statistical analysis of data on growth and yield variables in 'Agbagba' was performed with the NONORTHO subprogram of MSTAT-C software (Michigan State Univ., 1990). Data on phenotypic variation in 'Agbagba' and on seed set in 'Obino l'Ewai' were analyzed using $\chi^{2}$ tests.

\section{Results and Discussion}

Phenotypic variation. Phenotypic variants or off-types are commonly observed in clonal populations of plantains. Variants were observed in both False Horn plantain populations and exhibited changes in inflorescence morphology, resembling a French plantain (Vuylsteke et al., 1988, 1996). The $\chi^{2}$ test for independence indicated that phenotypic variation and propagation method were independent criteria $\left(\chi^{2}=1.16, P=0.28\right)$ (i.e., the ratio of true-to-type to off-type plants remained the same for both methods of plantain propagation). The more than two times higher variation frequency in the micropropagated plantains was not significantly different from that in the sucker-derived plantains (Table 1). The high frequency of variation in sucker-derived plantains and the absence of foliage variants in micropropagated plantains partly may explain the lack of significant difference. We did not expect both frequency distributions to be similar, as micropropagated 'Cavendish' bananas showed much higher rates of variation than conventionally propagated bananas (Drew and Smith, 1990; Smith, 1988). Also, earlier observations in the same plantain cultivar (Vuylsteke et al., 1988) suggested otherwise [Plantain and Banana Improvement Program (PBIP), 1993]. We infer that results of phenotypic variation rates are not always consistent over trials, which is corroborated by observations in other plantain cultivars (PBIP, 1993). Apparently, environment may greatly influence somaclonal variation rates. In general, however, off-type frequencies are higher in in vitro-derived plants than in field-propagated plants, even if the former are produced by micropropagation involving direct plant regeneration from shoot cultures and without an intervening callus phase (Smith, 1988; Smith and Drew, 1990; Vuylsteke et al., 1988, 1991).

Growth and yield characteristics. Only true-to-type plants were included in the analysis of variance for the horticultural performance of conventionally propagated vs. micropropagated plants of 'Agbagba' plantain. There were significant differences between in vitro- and sucker-derived plants only for plant height at 6 months after planting and at flowering and for height of the tallest sucker (follower) at harvest of the main pseudostem (Table 1).

In vitro plantain plants were significantly taller than conventional plants throughout the vegetative growth cycle, as illustrated by com- paring plant height at 6 months after planting and at flowering, which is the time of inflorescence emergence at the top of the pseudostem (Table 1). Plant height is a measure of plant vigor, indicating that in vitro plants established more quickly and grew vigorously. This vigor seems to be a general feature of micropropagated plantains and 'Cavendish' bananas (Drew and Smith, 1990; Hwang et al., 1984; Israeli et al., 1988; Robinson et al., 1993; Zamora et al., 1989) and is likely to result from the fact that in vitro propagules are cleaner and already possess an active root and shoot system at planting.

Vigorous and fast plantain growth generally results in earlier flowering and harvest (i.e., earlier maturity and a shorter production cycle) (Swennen and De Langhe, 1985). Indeed, in vitro plants flowered and were harvested 1 month earlier than sucker-derived plants (Table 1). However, this difference was not significant due to large intraclonal variation, particularly in the in vitro plants, as illustrated by a high standard error (Table 1), indicating that in vitro plantains produced a less uniform crop. This finding is contrary to reports on micropropagated 'Cavendish' bananas, a banana that generally produces a more uniform crop with in vitro plants than conventional materials (Hwang et al., 1984; Israeli et al., 1988; Janick and Ait-Oubahou, 1989). Fruit filling time, which is the time span between flowering and harvest, was the same for both propagation methods and was of a normal duration, $\approx 3$ months.

Fast-growing plantains emit new leaves at a faster rate, resulting in a larger leaf area during vegetative growth than in slow-growing plantains (Swennen and De Langhe, 1985). Hwang et al. (1984) and Israeli et al. (1988) noted that micropropagated 'Cavendish' bananas retained more healthy leaves than suckers due to a faster rate of leaf emission. However, the fast-growing in vitro plants of our experiment had the same number of standing leaves at flowering as the slower-growing conventional plants (Table 1). We suggest that the high pressure of black sigatoka leaf spot disease at the Onne station obliterated the advantage of the fast-growing in vitro plan-

Table 1. Off-type frequency, growth, and yield characteristics in clonal populations of the False Horn plantain (Musa spp., AAB group) 'Agbagba' according to propagation method.

\begin{tabular}{|c|c|c|c|}
\hline Trait & $\begin{array}{l}\text { Suckers } \\
(\mathrm{n}=86)\end{array}$ & $\begin{array}{c}\text { In vitro plants } \\
(\mathrm{n}=104)\end{array}$ & Difference \\
\hline Off-types (\%) ${ }^{\mathrm{z}}$ & 1.5 & 3.7 & $2.2^{\mathrm{Ns}}$ \\
\hline Plant height, $6 \mathrm{MAP}^{\mathrm{y}}(\mathrm{cm})$ & $173 \pm 2.6^{x}$ & $226 \pm 3.1$ & $53^{* *}$ \\
\hline Plant height, flowering $(\mathrm{cm})$ & $293 \pm 2.8$ & $316 \pm 2.4$ & $23^{*}$ \\
\hline Days to flowering & $357 \pm 3.4$ & $324 \pm 5.4$ & $-33^{\mathrm{Ns}}$ \\
\hline Standing leaf count & $11.2 \pm 0.2$ & $10.8 \pm 0.1$ & $-0.4^{\mathrm{Ns}}$ \\
\hline Youngest leaf spotted (BSD) & $7.2 \pm 0.1$ & $7.5 \pm 0.1$ & $0.3^{\mathrm{Ns}}$ \\
\hline Days for fruit filling & $90 \pm 0.8$ & $87 \pm 0.6$ & $-3^{\mathrm{Ns}}$ \\
\hline Days to harvest & $446 \pm 3.5$ & $411 \pm 5.5$ & $-35^{\mathrm{Ns}}$ \\
\hline Bunch weight (kg) & $5.1 \pm 0.2$ & $5.4 \pm 0.2$ & $0.3^{\mathrm{Ns}}$ \\
\hline Number of hands & $5.4 \pm 0.2$ & $6.2 \pm 0.1$ & $0.8^{\mathrm{Ns}}$ \\
\hline Number of fruit & $19.7 \pm 0.8$ & $20.4 \pm 0.6$ & $0.7^{\mathrm{Ns}}$ \\
\hline Fruit weight (g) & $263 \pm 7.6$ & $264 \pm 6.2$ & $1^{\mathrm{Ns}}$ \\
\hline Tallest sucker height $(\mathrm{cm})$ & $160 \pm 4.8$ & $118 \pm 4.7$ & $-42^{* * * *}$ \\
\hline
\end{tabular}

${ }^{2} n=195$ for suckers and $n=244$ for in vitro plants (border plants included).

${ }^{\mathrm{y}} \mathrm{MAP}=$ months after planting; BSD = black sigatoka disease.

${ }^{\mathrm{x}}$ Mean \pm SE of mean.

Ns, ${ }^{*}, * *, * * *$ Nonsignificant or significant at $P \leq 0.05,0.01$, or 0.001 , respectively. 
tains to retain more healthy leaves. In vitro and conventional plants were equally susceptible to black sigatoka disease, as shown by the scoring of the YLS at flowering (Table 1).

Bunch weight, and thus yield, was the same for both propagation methods. There also were no differences in the main yield components (number of fruit-bearing hands per bunch, total number of fruit per bunch, and average fruit weight) between in vitro and conventional plantains (Table 1). Although in vitro propagules grew significantly faster and taller, the expected higher yield (Swennen and De Langhe, 1985) was not obtained. The observed mean bunch weights were about half that of normal for 'Agbagba' at the Onne station, which weighed $\approx 11 \mathrm{~kg}$ (Swennen and Vuylsteke, 1987; Vuylsteke et al., 1996). We infer that black sigatoka, which causes yield losses of $\geq 33 \%$ in plantain (Mobambo et al., 1993), affected both types of planting material equally and significantly, as such obliterating the initial advantage of the in vitro plants. In addition to the absence of black sigatoka control by fungicide, the cultural practice applied to this trial also was less than optimal in that no mulch was added. Mulching enhances root development, vigorous growth, and high productivity of plantain (Swennen, 1990). It seems that good planting materials, such as in vitro plants, do not perform to expectation under suboptimal husbandry.

Reports on the yield performance of micropropagated banana plants of the 'Cavendish' subgroup are mixed. Some authors recorded significantly higher yields in micropropagated material (Daniells, 1988; Drew and Smith, 1990; Robinson et al., 1993) and others reported equal (Hwang et al., 1984; Zamora et al., 1989) or even lower yields (Israeli et al., 1988) than in conventional material. Thus, micropropagation does not seem to confer a consistent yield advantage to $M u s a$ plants, although in vitro plants establish more quickly and have vigorous initial growth.

The tallest sucker at harvest of the main stem was significantly shorter in micropropagated plantains compared to the suckerderived plants (Table 1). Height of the tallest sucker is an important component of perennial plantain productivity, as it is an indication of the development of the ratoon, which constitutes the next production cycle. Our results in this trial deviate from the general observation that fast-growing (i.e., in vitro) main pseudostems of plantain are accompanied by fast-growing suckers (Swennen and De Langhe, 1985). Shorter suckers can result from higher apical dominance, and one can only speculate on the potential carry-over effects of the growth regulators used in the tissue culture media on the reduced suckering in micropropagated plantains.

Botanical seed set. Seed production rates in the French plantain 'Obino l'Ewai' were equal in micropropagated and conventionally propagated plants $\left(\chi^{2}=0.28, P=0.60\right)$. Of the 80 sucker-propagated plants, 62 produced seed, giving a mean of 5.8 seeds per bunch. In the micropropagated population, 47 of the 65 plants produced seed, with a mean of 5.7 seeds per bunch. Seed set in this trial was similar to the average seed count for 'Obino l'Ewai' (Vuylsteke et al., 1993b). No data were recorded on growth and yield attributes of these two populations; therefore, we cannot relate this result to the vigor of the two propagule types. However, Shepherd(1954) and Swennen and Vuylsteke (1990) suggested that plant vigor and bunch size were positively correlated with seed set. Hence, we speculated that in vitro plants may produce more seed due to their generally greater vigor, but we could not confirm this guess during our investigation. Micropropagation has played a crucial role in the rapid deployment of IITA's plantain breeding program by rapidly supplying large numbers of plants of female-fertile plantain cultivars for crossing blocks (Vuylsteke et al., 1993a, 1993b). As such, it is important to note that micropropagated plantains do not produce less seed than sucker-derived plants.

We have shown that in vitro-produced plants of plantain and banana do not manifest consistently superior horticultural performance compared to sucker-propagated plants. Nevertheless, micropropagation remains an important technique for the establishment of large populations of newly bred or selected genotypes, and, thus, it is worthwhile emphasizing that there were no detrimental effects of in vitro propagation on horticultural performance. Furthermore, the improved phytosanitary status of in vitro plants makes them the planting material of choice to reduce the risk of pest and disease introduction in new plantings (Hwang et al., 1984) or for establishment of field nursery areas (Smith and Drew, 1990). These nurseries then can provide clean conventional planting material for production fields. Roguing of somaclonal variants also could be performed in such nurseries to avoid the occurrence of off-types in production fields at great economic loss to the plantain or banana farmer.

\section{Literature Cited}

Cronauer, S.S. and A.D. Krikorian. 1984. Rapid multiplication of bananas and plantains by in vitro shoot tip culture. HortScience 19:234235.

Daniells, J.W. 1988. Comparison of growth and yield of bananas derived from tissue culture and conventional planting material. Banana Nwsl. $11: 2$.

Drew, R.A. and M.K. Smith. 1990. Field evaluation of tissue-cultured bananas in south-eastern Queensland. Austral. J. Expt. Agr. 30:569-574.

Hwang, S.C., C.L. Chen, J.C. Lin, and H.L. Lin. 1984. Cultivation of banana using plantlets from meristem culture. HortScience 19:231-233.

Hwang, S.C. and W.H. Ko. 1987. Somaclonal variation of bananas and screening for resistance to Fusarium wilt, p. 151-156. In: G.J. Persley and E.A. De Langhe (eds.). Banana and plantain breeding strategies. Proc. Intl. Wkshp., Cairns, Australia, 13-17 Oct. 1986. ACIAR Proc. 21. Austral. Ctr. Intl. Agr. Res., Canberra.

Israeli, Y., O. Reuveni, and E. Lahav. 1991. Qualitative aspects of somaclonal variation in banana propagated by in vitro techniques. Scientia Hort. 48:71-88.

Israeli, Y., O. Reuveni, and N. Nameri. 1988. Genetic variability and performance of in vitro propagated banana plants, p. 97-104. In: J.A. Cháves and R.R. Calderón (eds.). Memorias 1986 de la IV Reunion sobre Agrofisiologia del banano. Asociación Bananera Nacional, San José, Costa Rica.

Janick, J. and A. Ait-Oubahou. 1989. Greenhouse production of banana in Morocco. HortScience 24:22-27.

Jarret, R.L., W. Rodriguez, and R. Fernandez. 1985. Evaluation, tissue culture propagation, and dissemination of 'Saba' and 'Pelipita' plantains in Costa Rica. Scientia Hort. 25:137-147.

Michigan State University. 1990. MSTAT-C. A microcomputer program for the design, management, and analysis of agronomic research experiments. Michigan State Univ., East Lansing.

Mobambo, K.N., F. Gauhl, D. Vuylsteke, R. Ortiz, C. Pasberg-Gauhl, and R. Swennen. 1993. Yield loss in plantain from black sigatoka leaf spot and field performance of resistant hybrids. Field Crops Res. 35:35-42.

Murashige, T. and F. Skoog. 1962. A revised medium for rapid growth and bioassays with tobacco tissue cultures. Physiol. Plant. 15:473497.

Plantain and Banana Improvement Program. 1993. Annual report 1992. Crop Improvement Div., Intl. Inst. Trop. Agr., Ibadan, Nigeria.

Ramcharan, C., A. Gonzalez, and W.I. Knausenberger. 1987. Performance of plantains produced from tissue-cultured plantlets in St. Croix, U.S. Virgin Islands, p. 36-39. In: International cooperation for effective plantain and banana research. Proc. 3rd Intl. Assn. Res. Plantain and Banana Mtg., Abidjan, Côte d'Ivoire, 27-31 May 1985. Intl. Network for the Improvement of Banana and Plantain, Montpellier, France.

Reuveni, O. and Y. Israeli. 1990. Measures to reduce somaclonal variation in in vitro propagated bananas. Acta Hort. 275:307-313.

Robinson, J.C., C. Fraser, and K. Eckstein. 1993. A field comparison of conventional suckers with tissue culture banana planting material over three crop cycles. J. Hort. Sci. 68:831-836.

Sandoval, J., A. Tapia, L. Müller, and V. Villalobos. 1991. Observaciones sobre la variabilidad encontrada en plantas micropropagadas de $M u s a$ cv. 'Falso Cuerno' AAB. Fruits 46:533-539.

Shepherd, K. 1954. Seed fertility of the Gros Michel banana in Jamaica. J. Hort. Sci. 29:1-11.

Simmonds, N.W. 1966. Bananas. 2nd ed. Tropical Agriculture Series. Longman, London and New York.

Smith, M.K. 1988. A review of factors influencing the genetic stability of micropropagated bananas. Fruits 43:219-223.

Smith, M.K. and R.A. Drew. 1990. Current applications of tissue culture in plant propagation and improvement. Austral. J. Plant Physiol. 17:267289.

Stover, R.H. 1987. Somaclonal variation in Grand Naine and Saba bananas in the nursery and field, p. 136-139. In: G.J. Persley and E.A. De Langhe (eds.). Banana and plantain breeding strategies. Proc. Intl. Wkshp., Cairns, Australia, 13-17 Oct. 1986. ACIAR Proc. 21. Austral. Ctr. Intl. Agr. Res., Canberra.

Swennen, R. 1990. Plantain cultivation under West African conditions. A reference manual. Intl. Inst. Trop. Agr., Ibadan, Nigeria.

Swennen, R. and E. De Langhe. 1985. Growth parameters of yield of plantain (Musa cv. AAB). Ann. Bot. 56:197-204.

Swennen, R. and D. Vuylsteke. 1987. Morphological taxonomy of plantain (Musa cultivars AAB) in West Africa, p. 165-171. In: G.J. Persley and E.A. De Langhe (eds.). Banana and plantain 
breeding strategies. Proc. Intl. Wkshp., Cairns, Australia, 13-17 Oct. 1986. ACIAR Proc. 21. Austral. Ctr. Intl. Agr. Res., Canberra.

Swennen, R. and D. Vuylsteke. 1990. Aspects of plantain breeding at IITA, p. 252-266. In: R.A. Fullerton and R.H. Stover (eds.). Sigatoka leaf spot diseases of bananas. Proc. Intl. Wkshp., San José, Costa Rica, 28 Mar.-1 Apr. 1989. Intl. Network for the Improvement of Banana and Plantain, Montpellier, France.

Tezenas du Montcel, H., E. De Langhe, and R. Swennen. 1983. Essai de classification des bananiers plantain (AAB). Fruits 38:461-474.

Vakili, N.G. 1968. Responses of Musa acuminata species and edible cultivars to infection by Mycosphaerella musicola . Trop. Agr. (Trinidad) 45:13-22.
Vuylsteke, D. 1989. Shoot-tip culture for the propagation, conservation, and exchange of Musa germplasm. Practical manuals for handling crop germplasm in vitro 2. Intl. Board for Plant Genetic Resources, Rome.

Vuylsteke, D. and E. De Langhe. 1985. Feasibility of in vitro propagation of bananas and plantains. Trop. Agr. (Trinidad) 62:323-328.

Vuylsteke, D., R. Ortiz, C. Pasberg-Gauhl, F. Gauhl, C. Gold, S. Ferris, and P. Speijer. 1993a. Plantain and banana research at the International Institute of Tropical Agriculture. HortScience 28:874, 970.

Vuylsteke, D., R. Swennen, and E. De Langhe. 1991. Somaclonal variation in plantains (Musa spp., AAB group) derived from shoot-tip culture. Fruits 46:429-439.
Vuylsteke, D., R. Swennen, and E. De Langhe. 1996. Field performance of somaclonal variants of plantain (Musa spp., AAB group). J. Amer. Soc. Hort. Sci. 121:42-46.

Vuylsteke, D., R. Swennen, and R. Ortiz. 1993b. Development and performance of black sigatokaresistant tetraploid hybrids of plantain (Musa spp., AAB group). Euphytica 65:33-42.

Vuylsteke, D., R. Swennen, G.F. Wilson, and E. De Langhe. 1988. Phenotypic variation among in vitro propagated plantain (Musa spp. cv. AAB). Scientia Hort. 36:79-88.

Zamora, A.B., O.P. Damasco, E.S. Estaño, R.C Barba, and L.F. Pateña. 1989. Growth and yield of micropropagated and sucker-derived banana plants (Musa spp., cvs. Lakatan, Bungulan and Saba). Philippine Agriculturist 72:458-465. 